\title{
Acute phase proteins: a potential approach for diagnosing chronic infection by Trypanosoma vivax
}

\author{
Proteínas de fase aguda: uma possível abordagem para diagnóstico \\ de infecção crônica por Trypanosoma vivax \\ Katyane de Sousa Almeida ${ }^{1 *}$; Alinny Ferreira Costa ${ }^{1}$; Paulo Cesar da Silva ${ }^{2}$; José Jurandir Fagliari²; \\ Rosangela Zacarias Machado ${ }^{3}$; Adjair Antonio do Nascimento ${ }^{3}$

\begin{abstract}
${ }^{1}$ Laboratório de Higiene e Saúde Pública, Escola de Medicina Veterinária e Zootecnia, Universidade Federal do Tocantins - UFT, Araguaína, TO, Brasil

${ }^{2}$ Departamento de Clínica e Cirurgia de Grandes Animais, Universidade Estadual Paulista - UNESP, Jaboticabal, SP, Brasil

${ }_{3}^{3}$ Departamento de Medicina Veterinária Preventiva e Reprodução Animal, Universidade Estadual Paulista - UNESP, Jaboticabal, SP, Brasil
\end{abstract}

Received May 18, 2011

Accepted February 13, 2012

\begin{abstract}
The present study aimed to assess potential changes in acute phase proteins in sheep experimentally infected with Trypanosoma vivax. There were studied eight male sheep, four used as controls and four infected with $10^{5} \mathrm{~T}$. vivax trypomastigotes. Blood samples were collected at two points times before infection and then at 5,7, 9, 11, 13, 15, 20, 30, 45, 60, 75, 90, 105 and 120 days post-infection (dpi). Blood samples were centrifuged and allotted, and acute phase proteins were then separated by electrophoresis on acrylamide gel containing sodium dodecyl sulfate. Protein concentrations were determined by computer-assisted densitometry. Total protein was determined by colorimetric biuret method. Trypanosomes were counted daily using a $5 \mathrm{~mL}$ aliquot of blood smear on a glass slide under a $22 \times 22 \mathrm{~mm}$ coverslip. Parasites were counted in 100 microscopic fields (40× magnification), and then multiplied by a correction factor. The results were expressed as parasites per $\mathrm{mL}$ of blood. For statistical analyses, we used the Wilcoxon test at 5\% significance level. There was found a reduction in several acute phase proteins and increase in antitrypsin and transferrin. This finding can be used for the diagnosis of T. vivax infection, especially in chronic infection.
\end{abstract}

Keywords: Antitrypsin, protein profile, transferrin, sheep.

\section{Resumo}

O objetivo do presente estudo foi verificar possíveis alteraçôes nas proteínas de fase aguda em ovinos infectados experimentalmente com Trypanosoma vivax. Para tanto, foram utilizados oito ovinos machos, sendo quatro usados como controle e quatro infectados com $10^{5}$ tripomastigotas de T. vivax. Colheram-se amostras de sangue em dois tempos antes da infecção e, posteriormente, aos 5, 7, 9, 11, 13, 15, 20, 30, 45, 60, 75, 90, 105 e 120 dias após a infecção (dpi); após centrifugação e aliquotização das amostras. As proteínas de fase aguda foram separadas por eletroforese em gel de acrilamida, contendo dodecil sulfato de sódio, e suas concentraçôes foram determinadas através de densitometria computadorizada. A dosagem de proteína total foi realizada pelo método colorimétrico do biureto. A contagem dos tripanossomas foi realizada diariamente, utilizando-se uma alíquota de $5 \mu \mathrm{L}$ de sangue disperso em lâmina de microscopia, sob lamínula de $22 \times 22 \mathrm{~mm}$, contando-se os parasitos em 100 campos microscópicos, com objetiva de 40x, multiplicados pelo fator de correçáo do microscópio, e o resultado expresso em parasitos por $\mathrm{mL}$ de sangue. Para a análise estatística, empregou-se o teste de Wilcoxon a 5\% de probabilidade. Foi observada a diminuiçáo de diversas proteínas de fase aguda e aumento de antitripsina e transferrina que podem ser utilizadas para auxiliar no diagnóstico da infecção por T. vivax, principalmente na fase crônica da infecção.

Palavras-chave: Antitripsina, proteinograma, transferrina, ovinos.

\footnotetext{
${ }^{*}$ Corresponding author: Katyane de Sousa Almeida

Laboratório de Higiene e Saúde Pública, Escola de Medicina Veterinária e

Zootecnia, Universidade Federal do Tocantins - UFT, BR 153, Km 112,

CP 132, CEP 77804-970, Araguaína, TO, Brasil

e-mail: katyanesalmeida@gmail.com
} 


\section{Introduction}

Trypanosoma vivax infects cattle and other domestic and wild ruminants (DÁVILA; SILVA, 2000). In Brazil this pathogen causes economic losses due to abortions, infertility, reduced performance, decreased production and mortality (SEIDL et al., 1999).

The diagnosis of animal trypanosomiasis may be difficult as there are no pathognomonic clinical signs of infection and standard trypanosome detection methods are not sensitive enough. Despite advances in the diagnosis of animal trypanosomiasis, many acute infections go unnoticed and a chronic form of disease, frequently with no parasitemia, is more prevalent (NANTULYA, 1990).

Animal trypanosomiasis is detected using parasitological, immunological and molecular diagnostic techniques. Micro-hematocrit centrifugation (Woo technique) is the most widely used technique as it can detect parasites six to 10 days earlier than with fresh blood smears. Although it is simple, Woo technique has low sensitivity for chronic infection (MASAKE et al., 1995).

Most immunological methods can detect antibodies to trypanosome antigens. Indirect immunofluorescence and ELISA are the most valuable methods, particularly for T. vivax distribution, because of their sensitivity and specificity. But cross-reactivity between antigens of parasites within the same genus is a major limitation of serological tests, reducing their specificity (NANTULYA, 1990; JONES; DÁVILA, 2001).

Other more sophisticated diagnostic techniques have been employed for T. vivax detection such as polymerase chain reaction (PCR). PCR was evaluated by Desquesnes (1997) and showed excellent results in frozen serum samples. It provided highly specific results with sensitivity similar to parasitological techniques, making it a valuable method for the analysis of field samples when well-equipped laboratories are not available.

The study of acute phase proteins can be a helpful approach for diagnosing $T$. vivax, especially in chronic infection when parasites are difficult to be detected in the bloodstream. According to Godson et al. (1996), the level of acute phase proteins changes during an infection, depending on the causative agent and the animal species infected. Acute protein profile can be used to facilitate the diagnosis of T. vivax infection.

Cerón et al. (2005) stressed that acute phase proteins increase in animals with different conditions but because of its low diagnostic specificity it is not used for primary diagnosis as a cause of disease cannot be determined. However, it is highly sensitive for detection of inflammation or subclinical infection. Although protein profile does not provide specific information, it can guide the diagnosis and prognosis of diseases.

Protein profiling is a significant approach for diagnosis and monitoring of several diseases in dogs (OHWADA; TAMURA, 1993; CÉRON et al., 2005) and calves infected with Mannheimia haemolytica (FAGLIARI et al., 2003). In addition, it has been used for prognosis postoperatively (FAGLIARI et al., 2008; SAQUETTI et al., 2008).

The present study aimed to assess potential changes in acute phase proteins in sheep experimentally infected with Trypanosoma vivax.

\section{Material and Methods}

The $T$. vivax sample was obtained from cattle in the region of Catolé do Rocha, northeastern Brazil. Two mL of blood with approximately $1.95 \times 10^{5} \mathrm{~T}$. vivax trypomastigotes were inoculated intravenously in an one-year-old no-breed male ovine for parasite multiplication. A total of eight no-breed male sheep, aged one year were used in the study. They went through a quarantine period for clinical, hematological, biochemical and stool examination, and detection of anti-T. vivax antibodies by indirect immunofluorescence assay (IFA). Healthy animals were kept in single stalls with raised floor and screened panels, fed a corn silage diet and water ad libitum and supplemented with mineral salt for 120 days. They were then randomly assigned to two groups: four were used as controls and the other four were infected intravenously with $1 \mathrm{~mL}$ of blood containing $10^{5}$ T. vivax trypomastigotes.

For monitoring parasitemia, from each animal inoculated with T. vivax trypomastigotes, $0.5 \mathrm{~mL}$ blood was collected daily from the jugular vein with $10 \%$ EDTA up to 120 days post infection (dpi). Trypanosomes were counted daily using a $5 \mathrm{~mL}$ aliquot of blood smear on a glass slide under a $22 \times 22 \mathrm{~mm}$ coverslip. Parasites were counted in 100 microscopic fields (40× magnification), and then multiplied by a correction factor. The results were expressed as parasites per $\mathrm{mL}$ of blood.

Three $\mathrm{mL}$ of blood were collected from the jugular vein without using an anticoagulant for serum analysis at 14 and 7 days before infection (for baseline, maximum and minimum values for each parameter evaluated) and then at 5, 7, 9, 11, 13, 15, 20, 30, 45, 60, 75, 90, 105 and 120 dpi.

Total protein was determined by the colorimetric biuret method using commercial kits (Labtest ${ }^{\circledR}$ Diagnóstica, Belo Horizonte, Brazil) and then read on a spectrophotometer (LabQuest ${ }^{\circledR}$ Diagnóstica, Belo Horizonte, Brazil).

Acute phase proteins were separated by electrophoresis on acrylamide gel containing sodium dodecyl sulfate(SDS-PAGE), as described by Laemmli (1970). After proteins were separated, the gel was stained with coomassie blue solution for $10 \mathrm{~min}$ and then added to a solution of $7 \%$ acetic acid to remove excess dye until protein fractions became evident. Protein concentrations were determined by computer-assisted densitometry (Shimadzu CS 9301, Tokyo) using as reference protein molecular weight markers (Sigma, St. Louis, MO, US) (29,000, 45,000, 66,000, 97,400, 116,000 and 205000 daltons), in addition to purified proteins (albumin, IgG, haptoglobin, $\alpha_{1}$-antitrypsin and transferrin).

All statistical analyses were performed in System for Statistical Analysis (SAEG) and nonparametric Wilcoxon test at 5\% significance level was used to assess changes in acute phase proteins.

\section{Results and Discussion}

The prepatent period was one day in one animal and two days in the other animals inoculated with parasites. Parasitemia was intermittent and its level varies in all infected animals up to $120 \mathrm{dpi}$.

Using the SDS-PAGE technique 26 plasma proteins were separated from the eight animals, and their molecular weights ranged from 13,000 to 170,000 daltons. Twelve showed statistically 
significant differences $(\mathrm{p}<0.05)$ (molecular weights in daltons): 138,000 (IgA); 130,000 (unknown); 125,000 (ceruloplasmin); 115,000 (unknown); 79,000 (hemopexin); 72,000 (transferrin); 60,000 (antitrypsin); 59,000 (heavy IgG); 55,000 (unknown); 51,000 (unknown); 32,000 (light IgG); 30,000 (unknown).

Of these 12 proteins with significant differences, 10 showed a reduction in the animals infected compared to controls. Four acute phase proteins had a significant reduction which was more markedly seen for ceruloplasmin and hemopexin. And antitrypsin and transferrin had an early reduction ( $5 \mathrm{dpi}$ ) in the animals infected compared to Day zero and controls, and then an increase above baseline in the chronic phase of infection with the highest levels seen for antitrypsin(Table 1).

Acute phase proteins are often measured at 2 hours intervals as they are no longer detectable in the chronic phase. But as parasitemia, though at lower levels, was maintained in sheep infected with $T$. vivax during the chronic phase of infection, the production of acute phase proteins was stimulated. Thus, the determination of acute phase proteins can help the diagnosis of T. vivax infection.

Ohwada and Tamura (1993) found that parvovirus infection in dogs can be diagnosed two weeks before the onset of clinical signs through increased levels of acid glycoprotein. Similar studies have shown that abnormal levels of a given acute phase protein may suggest a specific type of infection, which may help make a probable diagnosis. Like our study several studies in dogs have shown increasing levels of specific proteins in babesiosis, leishmaniasis, and parvovirus, Bordetella bronchiseptica, Escherichia coli and Ehrlichia canis infections and this knowledge allows to start treatment before clinical deterioration (CÉRON et al., 2005).

Fagliari et al. (2003) also described increased levels of ceruloplasmin, $\alpha_{1}$-antitrypsin, haptoglobin, and acid glycoprotein two hours after infection in calves with Mannheimia (Pasteurella) haemolytica, which suggests that these proteins can be measured for detecting preclinical disease.

Acute phase proteins usually increase during an infection. But the protein profile of the sheep here investigated showed a reduction in most proteins, except for transferrin and antitrypsin that increased. This same electrophoretic pattern was not described in any other condition, nor even in other trypanosome infections, which showed increased levels of proteins (Ndunguet et al., 1991). It is thus recommended the determination of transferrin and antitrypsin for the diagnosis of T. vivax because these proteins increase above baseline after $30 \mathrm{dpi}$, and together with clinical signs and/or other diagnostic methods, they may help diagnosing chronic infection (after $30 \mathrm{dpi}$ )given that parasite identification using routine diagnostic methods can be sometimes difficult due to low parasitemia.

Table 1. Means and standard deviations of total protein $(\mathrm{g} / \mathrm{dL})$ and acute phase proteins $(\mathrm{g} / \mathrm{dL})$ identified in the electrophoretic protein profile (SDS-PAGE) of sheep - controls and those experimentally infected with T. vivax during the experiment period.

\begin{tabular}{|c|c|c|c|c|c|c|c|c|c|c|c|c|c|c|c|}
\hline \multirow{2}{*}{$\begin{array}{c}\text { Protein } \\
(\mathrm{g} / \mathrm{dL})\end{array}$} & \multicolumn{15}{|c|}{ Days post infection } \\
\hline & $\mathbf{0}$ & 5 & 7 & 9 & 11 & 13 & 15 & 20 & 30 & 45 & 60 & 75 & 90 & 105 & 120 \\
\hline \multicolumn{16}{|c|}{ Total protein } \\
\hline Infected & $\begin{array}{l}5.31^{\mathrm{ns}} \\
(0.29)\end{array}$ & $\begin{array}{l}3.82^{\mathrm{b}} \\
(0.45)\end{array}$ & $\begin{array}{l}4.77^{\mathrm{ns}} \\
(0.13)\end{array}$ & $\begin{array}{l}5.03^{\mathrm{ns}} \\
(0.32)\end{array}$ & $\begin{array}{l}5.35^{\mathrm{ns}} \\
(0.72)\end{array}$ & $\begin{array}{c}4.81^{\mathrm{b}} \\
(0.78)\end{array}$ & $\begin{array}{c}4.85^{\mathrm{b}} \\
(0.16)\end{array}$ & $\begin{array}{r}4.70^{\mathrm{b}} \\
(0.94)\end{array}$ & $\begin{array}{l}5.03^{\mathrm{b}} \\
(0.55)\end{array}$ & $\begin{array}{l}5.41^{\mathrm{ns}} \\
(0.59)\end{array}$ & $\begin{array}{c}5.53^{\mathrm{ns}} \\
(0.25)\end{array}$ & $\begin{array}{c}7.17^{\mathrm{a}} \\
(0.43)\end{array}$ & $\begin{array}{l}6.61^{\mathrm{ns}} \\
(1.06)\end{array}$ & $\begin{array}{l}6.81^{\mathrm{ns}} \\
(0.87)\end{array}$ & $\begin{array}{l}7.28^{\mathrm{a}} \\
(0.72)\end{array}$ \\
\hline Controls & $\begin{array}{c}5.33^{\mathrm{ns}} \\
(0.14)\end{array}$ & $\begin{array}{l}6.14^{a} \\
(1.20)\end{array}$ & $\begin{array}{l}4.99^{\mathrm{ns}} \\
(0.44)\end{array}$ & $\begin{array}{l}5.46^{\mathrm{ns}} \\
(0.21)\end{array}$ & $\begin{array}{l}5.44^{\mathrm{ns}} \\
(0.46)\end{array}$ & $\begin{array}{l}5.85^{\mathrm{a}} \\
(0.67)\end{array}$ & $\begin{array}{l}5.49^{\mathrm{a}} \\
(0.24)\end{array}$ & $\begin{array}{c}6.13^{\mathrm{a}} \\
(0.40)\end{array}$ & $\begin{array}{l}6.02^{\mathrm{a}} \\
(0.43)\end{array}$ & $\begin{array}{l}5.91^{\text {ns }} \\
(0.43)\end{array}$ & $\begin{array}{l}5.86^{\mathrm{ns}} \\
(0.59)\end{array}$ & $\begin{array}{c}5.38^{b} \\
(0.03)\end{array}$ & $\begin{array}{l}6.00^{\mathrm{ns}} \\
(0.43)\end{array}$ & $\begin{array}{l}6.17^{\mathrm{ns}} \\
(0.52)\end{array}$ & $\begin{array}{c}6.30^{\mathrm{b}} \\
(0.34)\end{array}$ \\
\hline & $(0.015)$ & $(0.008)$ & $(0.007)$ & $(0.008)$ & $(0.008)$ & $(0.007)$ & $(0.006)$ & $(0.005)$ & $(0.005)$ & $(0.005)$ & $(0.005)$ & $(0.007)$ & $(0.005)$ & $(0.010)$ & $(0.010)$ \\
\hline Controls & $\begin{array}{c}0.030^{\text {ns }} \\
(0.004)\end{array}$ & $\begin{array}{c}0.037^{\mathrm{a}} \\
(0.009)\end{array}$ & $\begin{array}{r}0.030^{\mathrm{a}} \\
(0.005)\end{array}$ & $\begin{array}{c}0.031^{\mathrm{a}} \\
(0.005)\end{array}$ & $\begin{array}{c}0.032^{\mathrm{a}} \\
(0.006)\end{array}$ & $\begin{array}{c}0.038^{\mathrm{a}} \\
(0.008)\end{array}$ & $\begin{array}{c}0.033^{\mathrm{a}} \\
(0.008)\end{array}$ & $\begin{array}{c}0.037^{\mathrm{a}} \\
(0.008)\end{array}$ & $\begin{array}{c}0.036^{\mathrm{a}} \\
(0.008)\end{array}$ & $\begin{array}{c}0.035^{a} \\
(0.008)\end{array}$ & $\begin{array}{c}0.037^{\mathrm{a}} \\
(0.006)\end{array}$ & $\begin{array}{r}0.034^{a} \\
(0.007)\end{array}$ & $\begin{array}{r}0.037^{\mathrm{a}} \\
(0.008)\end{array}$ & $\begin{array}{r}0.039^{\mathrm{a}} \\
(0.005)\end{array}$ & $\begin{array}{r}0.036^{a} \\
(0.008)\end{array}$ \\
\hline \multicolumn{16}{|c|}{ Hemopexin } \\
\hline Infected & $\begin{array}{c}0.014^{\mathrm{ns}} \\
(0.004)\end{array}$ & $\begin{array}{c}0.009^{\mathrm{b}} \\
(0.001)\end{array}$ & $\begin{array}{c}0.011^{\mathrm{b}} \\
(0.002)\end{array}$ & $\begin{array}{c}0.010^{\mathrm{b}} \\
(0.002)\end{array}$ & $\begin{array}{c}0.011^{\mathrm{b}} \\
(0.004)\end{array}$ & $\begin{array}{c}0.007^{\mathrm{b}} \\
(0.002)\end{array}$ & $\begin{array}{c}0.007^{\mathrm{b}} \\
(0.002)\end{array}$ & $\begin{array}{c}0.005^{\mathrm{b}} \\
(0.002)\end{array}$ & $\begin{array}{c}0.004^{\mathrm{b}} \\
(0.002)\end{array}$ & $\begin{array}{c}0.004^{\mathrm{b}} \\
(0.001)\end{array}$ & $\begin{array}{c}0.004^{\mathrm{b}} \\
(0.002)\end{array}$ & $\begin{array}{c}0.005^{\mathrm{b}} \\
(0.004)\end{array}$ & $\begin{array}{r}0.007^{\mathrm{b}} \\
(0.007)\end{array}$ & $\begin{array}{c}0.006^{\mathrm{b}} \\
(0.004)\end{array}$ & $\begin{array}{c}0.005^{\mathrm{b}} \\
(0.003)\end{array}$ \\
\hline \multicolumn{16}{|c|}{ Transferrin } \\
\hline Infected & $\begin{array}{c}0.360^{\mathrm{ns}} \\
(0.069)\end{array}$ & $\begin{array}{c}0.237^{\mathrm{b}} \\
(0.027)\end{array}$ & $\begin{array}{c}0.376^{\mathrm{ns}} \\
(0.050)\end{array}$ & $\begin{array}{c}0.405^{\mathrm{ns}} \\
(0.069)\end{array}$ & $\begin{array}{r}0.522^{\mathrm{a}} \\
(0.076)\end{array}$ & $\begin{array}{c}0.512^{\text {ns }} \\
(0.050)\end{array}$ & $\begin{array}{c}0.485^{\text {ns }} \\
(0.056)\end{array}$ & $\begin{array}{c}0.513^{\text {ns }} \\
(0.143)\end{array}$ & $\begin{array}{c}0.664^{\mathrm{a}} \\
(0.076)\end{array}$ & $\begin{array}{c}0.744^{\mathrm{a}} \\
(0.193)\end{array}$ & $\begin{array}{c}0.634^{\mathrm{a}} \\
(0.063)\end{array}$ & $\begin{array}{c}0.745^{\mathrm{a}} \\
(0.097)\end{array}$ & $\begin{array}{r}0.620^{\mathrm{a}} \\
(0.035)\end{array}$ & $\begin{array}{c}0.588^{\mathrm{a}} \\
(0.091)\end{array}$ & $\begin{array}{c}0.570^{\text {ns }} \\
(0.143)\end{array}$ \\
\hline Controls & $\begin{array}{c}0.361^{\mathrm{ns}} \\
(0.064)\end{array}$ & $\begin{array}{c}0.394^{\mathrm{a}} \\
(0.120)\end{array}$ & $\begin{array}{c}0.352^{\mathrm{ns}} \\
(0.050)\end{array}$ & $\begin{array}{c}0.389^{\mathrm{ns}} \\
(0.073)\end{array}$ & $\begin{array}{c}0.401^{\mathrm{b}} \\
(0.096)\end{array}$ & $\begin{array}{c}0.397^{\mathrm{ns}} \\
(0.078)\end{array}$ & $\begin{array}{c}0.407^{\mathrm{ns}} \\
(0.082)\end{array}$ & $\begin{array}{c}0.407^{\mathrm{ns}} \\
(0.073)\end{array}$ & $\begin{array}{c}0.423^{\mathrm{b}} \\
(0.083)\end{array}$ & $\begin{array}{c}0.424^{\mathrm{b}} \\
(0.064)\end{array}$ & $\begin{array}{c}0.410^{\mathrm{b}} \\
(0.056)\end{array}$ & $\begin{array}{c}0.364^{\mathrm{b}} \\
(0.072)\end{array}$ & $\begin{array}{r}0.422^{\mathrm{b}} \\
(0.081)\end{array}$ & $\begin{array}{c}0.418^{b} \\
(0.074)\end{array}$ & $\begin{array}{c}0.448^{\text {ns }} \\
(0.062)\end{array}$ \\
\hline \multicolumn{16}{|c|}{ Antitrypsin } \\
\hline Infected & $\begin{array}{c}0.183^{\text {ns }} \\
(0.010)\end{array}$ & $\begin{array}{c}0.147^{b} \\
(0.027)\end{array}$ & $\begin{array}{c}0.182^{\mathrm{ns}} \\
(0.007)\end{array}$ & $\begin{array}{c}0.198^{\mathrm{ns}} \\
(0.006)\end{array}$ & $\begin{array}{c}0.219^{\mathrm{a}} \\
(0.025)\end{array}$ & $\begin{array}{c}0.184^{\mathrm{ns}} \\
(0.051)\end{array}$ & $\begin{array}{c}0.206^{\mathrm{ns}} \\
(0.025)\end{array}$ & $\begin{array}{c}0.181^{\mathrm{ns}} \\
(0.030)\end{array}$ & $\begin{array}{c}0.207^{\mathrm{ns}} \\
(0.042)\end{array}$ & $\begin{array}{c}0.291^{\mathrm{a}} \\
(0.090)\end{array}$ & $\begin{array}{r}0.355^{a} \\
(0.105)\end{array}$ & $\begin{array}{c}0.530^{\mathrm{a}} \\
(0.127)\end{array}$ & $\begin{array}{r}0.548^{\mathrm{a}} \\
(0.236)\end{array}$ & $\begin{array}{c}0.610^{\mathrm{a}} \\
(0.196)\end{array}$ & $\begin{array}{r}0.702^{\mathrm{a}} \\
(0.203)\end{array}$ \\
\hline Controls & $\begin{array}{l}0.171^{\mathrm{ns}} \\
(0.015)\end{array}$ & $\begin{array}{c}0.185^{\mathrm{a}} \\
(0.028)\end{array}$ & $\begin{array}{c}0.164^{\mathrm{ns}} \\
(0.048)\end{array}$ & $\begin{array}{c}0.169^{\mathrm{ns}} \\
(0.025)\end{array}$ & $\begin{array}{c}0.155^{\mathrm{b}} \\
(0.030)\end{array}$ & $\begin{array}{c}0.192^{\mathrm{ns}} \\
(0.052)\end{array}$ & $\begin{array}{c}0.181^{\mathrm{ns}} \\
(0.025)\end{array}$ & $\begin{array}{c}0.193^{\text {ns }} \\
(0.040)\end{array}$ & $\begin{array}{c}0.189^{\mathrm{ns}} \\
(0.029)\end{array}$ & $\begin{array}{c}0.183^{\mathrm{b}} \\
(0.031)\end{array}$ & $\begin{array}{c}0.187^{\mathrm{b}} \\
(0.047)\end{array}$ & $\begin{array}{c}0.164^{\mathrm{b}} \\
(0.046)\end{array}$ & $\begin{array}{c}0.169^{\mathrm{b}} \\
(0.027)\end{array}$ & $\begin{array}{c}0.180^{\mathrm{b}} \\
(0.045)\end{array}$ & $\begin{array}{r}0.175^{\mathrm{b}} \\
(0.047)\end{array}$ \\
\hline
\end{tabular}

Means followed by the same letter are not statistically different in the Wilcoxon test at $5 \%$ significant level. ns Non significant in the Wilcoxon test at $5 \%$ significant level. Standard deviations in brackets. 
The electrophoretic profile of acute phase proteins has the additional advantages of reducing costs and not requiring preparation of glass slides with trypanosomes (as in IFA), and in vitro or in vivo parasite growth, which may be a complex procedure involving inoculation of T. vivax in laboratory animals and preparation of antigens for diagnostic use.

\section{Conclusions}

The electrophoretic protein profile in sheep infected with T. vivax showed a different pattern with a reduction of several acute phase proteins and an increase in antitrypsin and transferrin. These proteins can be used to help diagnose infection, especially chronic infection.

\section{References}

Cerón JJ, Eckersall PD, Martinez-Subiela S. Acute phase proteins in dogs and cats: current knowledge and future perspectives. Vet Clin Pathol 2005; 34(2): 85-99. http://dx.doi.org/10.1111/j.1939-165X.2005. tb00019.x

Dávila AMR, Silva RAMS. Animal Trypanosomiasis in South America: Current Status, Partnership, and Information Technology. Ann NYAcad Scie 2000; 916: 199-212. PMid:11193622.

Desquesnes M. Evaluation of a simple PCR technique for the diagnosis of Trypanosoma vivax infection in the serum of cattle in comparison to parasitological techniques and antigen-enzyme-linked immune sorbent assay. Acta Tropica 1997; 65(3): 139-148. http://dx.doi.org/10.1016/ S0001-706X(96)00643-2

Fagliari JJ, Weiss DJ, McClenanhan D, Evanson OA. Serum protein concentrations in calves with experimentally induced pneumonic pasteurellosis. Arq Bras Med Vet Zootec 2003; 55(4): 383-387. http:// dx.doi.org/10.1590/S0102-09352003000400001

Fagliari JJ, Silva SL, Silva PC, Pereira GT. Leucograma e teores plasmáticos de proteínas de fase aguda de eqüinos portadores de abdômen agudo e submetidos à laparotomia. Arq Bras Med Vet Zootec 2008; 60(2): 322-328. http://dx.doi.org/10.1590/S0102-09352008000200007

Godson DL, Campos M, Attah-Poku SK, Redmond MJ, Cordeiro DM, Sethi MS, et al. Serum haptoglobin as an indicator of the acute phase response in bovine respiratory disease. Vet Immun 1996; 51(3-4): 277-292. http://dx.doi.org/10.1016/0165-2427(95)05520-7

Jones TW, Dávila AMR. Trypanosoma vivax - out of Africa. Trends Parasitol 2001; 17(2):99-101. http://dx.doi.org/10.1016/ S1471-4922(00)01777-3

Laemmli UK. Cleavage of structural proteins during the assembly of the head of bacteriophage $\mathrm{T}_{4}$. Nature 1970; 227: 680-685. PMid:5432063. http://dx.doi.org/10.1038/227680a0

Masake RA, Moloo SK, Nantulya VM, Minja SH, Makau JM, Njuguna JT. Comparative sensitivity of antigen-detection enzyme immunosorbent assay and the microhaematocrit centrifugation technique in the diagnosis of Trypanosoma brucei infections in cattle. Vet Parasitol 1995; 56(1-3): 37-46. http://dx.doi.org/10.1016/0304-4017(94)00667-2

Nantulya VM. Trypanosomiasis in domestic animals: the problems of diagnosis. Rev Sci Tech Off Int Epiz 1990; 9(2): 357-367.

Ndungu JM, Eckersall PD, Jennings FW. Elevation of the concentration of acute phase proteins in dogs infected with Trypanosoma brucei. Acta Tropica 1991; 49(2): 77-85. http://dx.doi. org/10.1016/0001-706X(91)90055-O

Ohwada K,Tamura K. Usefulness of alpha 1 acid glycoprotein (alpha 1-AG) values in screening pound dogs acquired from animal shelters for experimental use. Exp Anim 1993; 42(2): 627-630.

Saquetti CHC, Faleiros RR, Macoris DG, Fagliari JJ, Silva SL. Perfil eletroforético do proteinograma sérico de equinos com obstrução experimental do cólon menor. Arq Bras Med Vet Zootec 2008; 60(4): 794-799. http://dx.doi.org/10.1590/S0102-09352008000400003

Seidl A, Dávila AMR, Silva RAMS. Estimated Financial Impact of Trypanosoma vivax on the Brazilian Pantanal and Bolivian Lowlands. Mem Inst OswaldoCruz 1999; 94(2): 269-272. http://dx.doi.org/10.1590/ S0074-02761999000200027 